\title{
Livet er for kort til kvindefodbold \\ - om kvindefodbold, homofobi og (re)præsentationer af homofobi i den danske avispresse
}

\author{
Af Anne Brus
}

Sport er historisk set et område, hvor mænd har forstærket deres maskulinitet og fremhævet deres forskellighed fra kvinder. Derfor repræsenterer en sport som fodbold en vigtig arena for den sociale konstruktion af maskulinitet. ${ }^{1}$ Socialt set er fodbold et mandligt domæne, hvor maskulin solidaritet udvides, og hvor sporten fungerer som en identitets- og træningsform for maskulinitet. Denne måde at konstruere og demonstrere maskulinitet på i fodbold kaldes for hegemonisk maskulinitet. ${ }^{2}$ Den hegemoniske maskulinitet har gjort det svært for kvinder at få lov til at spille fodbold.

I den forbindelse antages det, at kvinder, der har valgt at dyrke en sport, her fodbold, som traditionelt set har været forbeholdt mænd, er mere udsatte for at blive stigmatiseret og marginaliseret omkring deres seksualitet. $^{3}$

Således er kvindefodbold en sport, der ofte er blevet latterliggjort og kritiseret på forskellige måder, bl.a. ved at beskylde kvinderne for at være maskuline og stigmatisere dem som lesbiske. En kvindelig fodboldspiller formulerer det på følgende måde:

»... det bliver fort sånn mistanker og liksom, hvis du da spiller fotball og ser litt maskulin ut, så er det iallefall veldig lett å få rykte på seg: 'Ja hun må vare lesbisk' «. ${ }^{4}$
Også i Danmark bliver kvindefodbold og homoseksualitet fremhævet som et problem. I forbindelse med sit feltarbejde er en idrætsforsker ude at observere et kvindefodboldhold. Idrætsforskeren bliver mødt med følgende replik: »Hvis du leder efter lesbiske kvinder, så må du finde en anden klub at udføre din unders $\phi$ gelse ${ }^{5}{ }^{5}$ Og i en fjernsynsudsendelse om kvinder i sport postulerer en dansk idrætspsykolog, at kvinder bliver lesbiske af at spille fodbold. ${ }^{6}$

Disse postulater omkring de fodboldspillende kvinders seksualitet er tilsyneladende langt mere omfattende end hidtil antaget, og disse homofobiske holdninger, som både fodboldtræneren og idrætspsykologen giver udtryk for, er et stigende problem for de kvinder, der spiller fodbold - ikke mindst for elitesportsudøvere, der konstant er i offentlighedens søgelys. Specielt medierne er blevet gjort ansvarlige for disse rygter om kvindefodbold og homoseksualitet, fordi de i for høj grad fokuserer på kvindernes eventuelle homoseksualitet i stedet for at interessere sig for selve fodboldspillet. $^{7}$

I Danmark har der ikke været skabt en debat om kvindefodbold og homofobi, bortset fra en enkelt artikel i DGI's (Danske Gymnastik \& Idrætsforeninger) medlemsblad. ${ }^{8}$ Det vil jeg med denne artikel fors $\varnothing$ ge at råde bod på. 
Mediebilledet er i sig selv meget omfattende, så for at begrænse det empiriske materiale har jeg valgt at koncentrere mig om det skrevne medie, altså aviserne.

Med udgangspunkt i en indkredsning af homofobi-begrebet har jeg i artiklen analyseret, hvorledes homofobiske holdninger kommer til udtryk inden for kvindesporten generelt og mere specifikt inden for kvindefodbold. Dernæst har jeg i et historisk tilbageblik belyst, hvorledes kvindefodbold fra det spæde fors $\emptyset \mathrm{g}$ på at etablere sig som en sportsgren for kvinder i slutningen af 1800-tallet og frem til det nye årtusindeskift har været præget af den antagelse, at kvinder bliver mere maskuline af at spille fodbold, og hvorledes denne antagelse har ført til, at kvindelige fodboldspillere, uafhængig af deres seksuelle orientering, kan mistænkes for at være lesbiske. Endvidere er analyserammen anvendt til et studie af, hvordan de danske aviser indenfor de sidste fem år har (re)præsenteret kvindefodbold.

\section{Hvad er homofobi?}

Ordet fobi er et psykologisk udtryk, som indikerer en eller anden form for frygt over for $»$ noget $\ll$. Homofobi er således angsten for omgang med éns eget køn eller en angst - og afsky ved homoseksuelle. I ekstreme tilfælde af vold kan homofobi være voldsmandens identitetsskabende besværgelse af egen maskulinitet - eller sagt på en anden måde kan homofobi tolkes som en persons maskerede frygt for egne homoseksuelle impulser. ${ }^{9}$

Homofobi-begrebet er blevet kritiseret for dets tilknytning til psykologien ud fra den betragtning, at begrebet bliver individualiserende og dermed leder tankerne væk fra de homofobiske holdningers samfundsmæssige baggrund. Eksempelvis pe- ges der på, at homofobi-begrebet ikke er anvendeligt til at beskrive diskriminationen imod homoseksuelle i samfundet som helhed. Derfor foretrækker visse forskere at benytte begrebet homonegativisme, fordi man herigennem kan udtrykke en mere direkte og målbevidst holdning imod homoseksuelle. ${ }^{10}$ Homonegativisme defineres på følgende måde:

»... som mere målbevidste, ikke irrationelle negative holdninger og adford overfor ikke-heteroseksuelle personer $«{ }^{11}$

Ved at anvende begrebet homonegativisme undgår man således det individuelle, psykologiske præg, som homofobi-begrebet er blevet kritiseret for at have. Derfor peger flere forskere på, at både homofobi og homonegativisme som begreber er anvendelige $i$ en analyse, betinget af i hvilken sammenhæng de anvendes. ${ }^{12}$

Et samfund kan være bygget op på en såkaldt homofobisk kultur, hvori homoseksuelle uden grund bliver gjort kriminelle og diskrimineret. Derfor lader homofobi sig ikke reducere til et spørgsmål om frygt hos den enkelte, men kan ses som en afspejling af en kulturel overlevering, hvori seksuel samkvem mellem mennesker af samme $k ø n$ anses for at være væsensforskelligt, suspekt og forklaringskrævende. ${ }^{13}$ I en sådan fortolkning af homofobi kan begrebet bruges til at beskrive den angst og frygt, der opstår, når kvinder og mænd ikke opfører sig, som man forventer - ud fra det som anses for at være en »normal« seksuel orientering, altså set $\mathrm{i}$ forhold til det at være heteroseksuel.

Homoseksuelle kan opfattes som en trussel mod den sociale orden, set i forhold til de etablerede magtforhold mellem kvinder og mænd..$^{14}$ Derfor kan homofobiske holdninger være med til at opretholde de 
traditionelle kønsrollemønstre ${ }^{15}$ i samfundet. Homofobiske holdninger udøves ofte af folk, som er negative over for en ligestilling mellem kønnene og til forandringer i forholdene mellem kønnene. ${ }^{16}$

Således er homofobi ikke kun et fænomen, som rammer lesbiske og bøsser. Også heteroseksuelle kvinder kan udsættes for homofobi, når de afviger fra, hvordan man forventer, at kvinder skal eller bør opføre sig. Homofobi defineres som

»... en irrationel frygt og intolerance overfor homoseksuelle, og overfor adfard som afviger fra traditionelle kønsrolleforventninger ${ }^{17}{ }^{17}$

I denne artikel anvendes definitionen af begrebet homofobi, fordi det ikke kun relaterer sig til homoseksuelle, men også omfatter heteroseksuelle. Derved bliver analysens fokus lagt på den potentielle undertrykkelse af alle kvinder, der spiller fodbold.

\section{Hvad er homofobi $i$ kvindesport?}

Seksuel normalitet og afvigelse har historisk set ændret sig gennem tiderne. Eksempelvis er den medicinske betegnelse og diagnose for homoseksualitet i 1980'erne blevet sløjfet i det amerikanske klassifikationssystem for psykiatriske diagnoser DSM (Diagnostic and Statistical Manual of Mental Disorders). Til trods for disse fors $\varnothing \mathrm{g}$ på klinisk at normalisere homoseksualitet som en seksuel orientering på lige fod med heteroseksualitet er opfattelsen af homoseksualitet som en seksuel afvigelse først og fremmest afhængig af kulturspecifikke sociale konventioner. ${ }^{18}$

Homofobi i kvindesporten er i særdeles- hed blevet unders $\varnothing \mathrm{gt}$ af amerikanske og canadiske forskere. Det er dog vanskeligt at overføre den amerikanske og canadiske forskning på grund af kulturelle forskelle. Disse landes åbenhed over for homoseksualitet er på det lovgivningsmæssige plan vidt forskellig fra Danmark. I Danmark er det eksempelvis tilladt for lesbiske og bøsser at indgå $i$ et registreret partnerskab. Selvom Danmark er nået langt på det officielle plan i forhold til at acceptere homoseksualitet som en seksualitet og ikke en sygdom eller psykiatrisk lidelse, er der alligevel en lang vej til at acceptere bøsser og lesbiske på det følelsesmæssige plan. Derfor er den stigmatisering af homoseksuelle, som stadigvæk eksisterer i samfundet, vigtig for både de heteroseksuelle og de lesbiske sportsudøvere.

Homofobiske holdninger kan blive et magtfuldt våben, som kan bruges til at udelukke kvinder fra at dyrke sport. Betegnelsen »lesbisk « bruges i den forbindelse til at definere grænserne for, hvad der er acceptabel kvindelig adfærd. Når en kvinde bliver kaldt lesbisk, har hun overskredet grænsen for, hvad normerne for kvindelighed kræver af hende som kvinde.

Homofobiske holdninger over for sportskvinder kan komme til udtryk på følgende måde:

Ved tavshed. Der bliver ikke snakket åbent om eventuelle lesbiske i klubben, og derfor er det vanskeligt for lesbiske sportsudøvere at »springe ud og stå frem « som homoseksuel. ${ }^{19}$ Af samme årsag foretrækker nogle lesbiske at forholde sig tavse om deres seksualitet. Den amerikanske kvinde- og idrætforsker Pat Griffin (1998) illustrerer dette problem ved at kalde sin bog om homofobi for Strong Women, deep Closet.

Der er tilsyneladende mere åbenhed på vej i de nordiske lande omkring lesbiske 
elitesportsudøvere. Således valgte den danske håndboldstjerne Camilla Andersen ved OL i Sydney 2000 at offentliggøre sit registrerede partnerskab med en kendt norsk kvindelig håndboldstjerne, men om dette eksempel er en handling, der kommer til at stå alene, er på nuværende tidspunkt vanskeligt at forudse.

Ved forncegtelse. Ved en direkte forespørgsel nægter visse trænere og ledere, at der er lesbiske i klubben eller på landsholdet. Det kan være af hensyn til sponsorere i klubben, der mener, at lesbiske i sporten kan $\varnothing$ delægge deres $»$ public image $\ll{ }^{20}$ For de kvindelige sportsudøveres vedkommende kan nogle kvinder i elitesporten være åbne omkring deres seksualitet, mens andre kvinder er nødt til at svare benægtende eller lyve om tilstedeværelsen af lesbiske i deres respektive klubber. ${ }^{21}$ Der er også flere kvindelige elitefodboldspillerne, der svarer benægtende eller lyver, når nogle uden for fodboldmiljøet spørger om, der er lesbiske på fodboldholdet. En norsk fodboldspiller formulerer det på følgende måde:

»Når folk spфr: Er der mange sånne på laget ditt?, så sier jeg nei, for det har de ikke noe med. Det gidder jeg ikke å prate om, for det er ikke positivt. Jeg gidder ikke å prate negativt om klubben min, eller om damefotballen generelt liksom $\ll{ }^{22}$

Den tidligere amerikanske tennisstjerne Martina Navratilova har ved flere pressekonferencer følt sig presset til at fornægte sin lesbiske identitet af angst for ikke at få lov til at blive amerikansk statsborger. Også den tidligere amerikanske tennisstjerne Billie Jean King har flere gange offentligt nægtet at vedkende sig sin homoseksualitet. ${ }^{23}$

Ved et heteroseksuelt udtryk. Hvis man opfatter heteroseksualitet som en institution og et organiserende princip i forhold til måden, hvorpå der dannes sociale relationer i sporten, kan det hævdes, at heteroseksualitet er den eneste rationelle, naturlige og acceptable seksuelle orientering i sport. I den forbindelse fremtræder kvindelighed som et kodeord for heteroseksualitet. $^{24}$

Ud fra et feministisk poststrukturalistisk teoretisk perspektiv kan der peges på to diskursive praksiser, som har betydning for kvinder, der spiller fodbold - den heteroseksuelle diskurs og sportsdiskursen. Den heteroseksuelle diskurs konstruerer den maskuline krop som stærk og aktiv og den feminine krop som svag og passiv. Disse to diskurser er modsætningsfyldte konstruktioner, som skaber problemer for de kvinder, som afviger fra den tilladte norm af kvindelighed ved at have kort hår og en atletisk krop. Da det feminine udtryk bliver opfattet som et kodeord for heteroseksualitet, vil disse kvinder blive opfattet som lesbiske uden nødvendigvis at være det. Fodboldspillende kvinder kan derfor være nødsaget til at fremtræde som heteroseksuelle og feminine for at undgå homofobiske holdninger i sporten og fra medierne i særdeleshed. $^{25}$

Der er således tre forskellige måder, hvorpå en sportsudøver kan forsøge at legitimere sin heteroseksualitet: 1) ved at synliggøre et heteroseksuelt parforhold, eksempelvis ved at lade sig fotografere med sin mand og eventuelle børn, 2) ved at fremhæve sin kvindelighed, eksempelvis ved at have langt hår og have håret bundet op i en hestehale, anvende makeup eller gå i feminint tøj, eller 3) ved at lade være med at udtale sig i positive vendinger om lesbiske eller ikke vise sympati for lesbiske. ${ }^{26}$

Denne nødvendige legitimering af sportsudøveres heteroseksualitet har eksempel- 
vis fået sponsorer til at diktere et feminint »look « hos fodboldspillerne. Men også visse sportsledere er optaget af, at de kvindelige landsholdsspillere skal se feminine ud, når de optræder i landsholdssammenhæng, for at offentligheden ikke skal få mistanke om, at der er lesbiske på holdet. $^{27}$

Ved direkte at angribe lesbiske sportsud$\phi$ vere. Inden for de sidste 15 år er der sket en ændring i måden, hvorpå lesbiske sportsudøvere behandles i pressen. Hvor pressen tidligere vægtede at insinuere og sprede rygter om en sportsudøvers eventuelle homoseksualitet, er det nu mere almindeligt, at pressen angriber lesbiske sportsudøvere direkte for deres homoseksualitet. ${ }^{28}$ Der findes desuden flere eksempler på klubber, som har »udrenset « klubben for homoseksuelle, eller som officielt har udtalt, at klubben ikke tager imod lesbiske. ${ }^{29}$

Ved at foretrakke mandlige tranere. Forældre kan være bange for, at de kvindelige trænere er lesbiske, og at deres eventuelle homoseksualitet smitter. Derfor undgår forældrene at sende deres døtre til klubber, hvor der er kvindelige trænere. Lesbiske trænere står $\mathrm{i}$ et dårligt lys, fordi man anser lesbiske som dårlige rollemodeller for børn. Specielt i den amerikanske sportsverden inden for eksempelvis softball, basketball, tennis, ishockey og golf er dette fænomen fremtrædende. ${ }^{30}$ Dette kunne være med til at påvirke rekrutteringen til kvindefodbold. Også selvom nyere forskning antyder, at det er langt mere sandsynligt, at der opstår et seksuelt forhold mellem en mandlig træner og en ung kvindelig udøvere. ${ }^{31}$

I Danmark er der ikke antydning af en sådan rekrutteringsproblematik. Ifølge de seneste offentliggjorte medlemstal fra DIF (Dansk Idræts-Forbund) for år 2001 er der i Danmark 44.353 piger og kvinder, der spiller fodbold. I forhold til sidste år står kvindefodbold således til en fremgang på 2.037 spillere og er den femte største sportsgren for kvinder i Danmark. Kvindelige fodboldspillere oplever tilsyneladende ikke den eventuelle konflikt, der kunne ligge $i$ at være kvinde og deltage $i$ en i forhold til traditionerne maskulin sportsgren som fodbold. Kvinderne har været i fodboldkulturen siden barndommen. På denne måde er fodboldspillet blevet »kønnet « og gjort kvindeligt for dem gennem gentagne kropslige fodbolderfaringer, og derfor fremstår fodboldspillet som en helt naturlig del af kvindernes kønsidentitet. ${ }^{32}$

\section{Angsten for amazonen ${ }^{33}$ - et historisk tilbageblik}

Homofobiske holdninger har usynlige tråde, der historisk set kan spores tilbage til slutningen af 1800 -tallet. ${ }^{34}$ Forestillingen om, at fodbold gør kvinder til mænd, eller at de »mandliggøres«, kunne man bl.a. læse om i Dansk Idræts-Forbunds officielle blad Idrcetten i 1918:

\section{$»$ Til Fodboldkvinderne:}

[...] Findes der da ingen venlige Mennesker, som kan gøre Damerne begribeligt, at Fodbold, som maaske kan vare et Spil for Herrer, absolut ikke er et Spil for Damer [...] Et skrutrygget Kvindemenneske, som farer omkring i Mandfolkebukser og Fodboldst $\phi v l e r$, med gyngende Bryst og skriger 'Offside' og 'Skyd din Honisse' - nej, jeg tror ikke, at vi drømmer noget sarligt om en saadan Person«.

Der var grænser for, hvilken sportsaktivitet kvinder kunne tillade sig at dyrke. Det fătal af kvinder, der var interesseret $i$ at spille 
fodbold, fik tilbudt en tid klokken seks om morgenen i et indelukket eksercerhus eller blev gjort til grin i den offentlige debat. ${ }^{35}$ Fodboldspillende kvinder brød med de normer for kvindelighed, der herskede omkring århundredeskiftet, og som var relateret til kvindens rolle som mor, kvindens krop og seksualitet.

Specielt lægerne med deres naturvidenskabelige erkendelse som et vigtigt vidensgrundlag anså sport som direkte skadeligt for kvindekroppen, i særdeleshed for kvinders reproduktionsevne. ${ }^{36}$ Eksempelvis havde den danske læge Franz Howitz allerede i 1892 advaret kvinder mod at dyrke visse former for legemlig udfoldelse, der kunne skade de unge pigers indvendige organer og funktioner på en sådan måde, at deres vordende moderskab og rolle som hustru kom i fare.

Kvinders seksualitet var også underlagt mandens i den forstand, at man ikke opfattede kvinder som seksuelt aktive, og kvinderne blev derfor heller ikke opfattet som en trussel mod mændenes seksualitet. Kvinders allerede eksisterende undertrykte sociale position havde med den engelske filosof Herbert Spencer fået et biologisk grundlag. Spencer drog paralleller mellem dyr og menneske, hvorved manden i den seksuelle akt blev opfattet som den aktive og pågående part og kvinden som den passive og modtagende part. ${ }^{37}$

Til trods for lægernes advarsler om sportens skadelige virkninger for kvindekroppen ses der en markant stigning af aktive kvinder inden for visse grene af sporten, specielt i mellemkrigstiden. ${ }^{38}$ De fleste kvinder valgte at dyrke gymnastik, som var et område af sporten, der ifølge samfundets normer var tilladelig legemlig udfoldelse, men et fåtal af kvinderne bevægede sig ind i sportens $»$ mindre kvindelige og mindre acceptable« verden. Dog ikke til kvinde- fodbold, der ikke formåede at etablere sig som en sportsgren for kvinder.

Det blev i stedet kvinders deltagelse i atletik, der i 1930'erne var med til at skærpe debatten om, hvad kvinder kunne og burde dyrke af sport. Atletikkens krav om at springe højest, hoppe længst og løbe hurtigst var et brud på, hvad der blev opfattet som kvindeligt, og i forhold til hvad de medicinske argumenter satte af grænser for, hvad kvindekroppen kunne tåle. Det var således lægerne, der fastslog, at den intensive træning og konkurrence ændrede kvindekroppen på en sådan måde, at kroppen ikke længere blev opfattet som seksuel attraktiv for mænd. I forlængelse heraf blev det i den offentlige debat påstået, at sporten gjorde kvinder mere maskuline og til mænd.

Denne sammenblanding af medicinske og moralske argumenter i den offentlige debat skyldtes ifølge den danske idrætshistoriker Hans Bonde mænds »angst for amazonen «. ${ }^{39}$

De stærke, hurtige muskuløse kvinder blev opfattet som en trussel mod mændenes mandighed. ${ }^{40}$

Visse idrætsforskere ${ }^{41}$ har peget på, hvorledes synet på sportskvinderne omkring 1930'erne tilsyneladende ændrede sig, fordi de sportsaktive kvinder blev opfattet som en trussel mod mændenes magt og seksualitet. Flere af de daværende kvindelige amerikanske sportsudøvere blev hængt ud som kønslige mærkværdigheder i den amerikanske presse. Eksempelvis tiltrak den amerikanske atlet Babe Didrikson i 1930'erne den amerikanske presses opmærksomhed. Ikke kun på grund af hendes usædvanlige talent for sport, men også fordi hun overskred grænserne for, hvad man forventede af hende som kvinde. Når hendes præstationer blev omtalt i pressen, blev de efterfulgt af beskrivelser, der frem- 
hævede hendes mandige, ufeminine og hårde fremtoning. $\mathrm{Og}$ hun blev ved flere lejligheder beskrevet som »a muscle moll «. ${ }^{42}$ Også i de nordiske lande fandt der en ændring sted i synet på sportskvinderne. Begrebet »heteroseksuelt mislykket « blev i denne periode anvendt til at beskrive kvinders manglende seksuelle tiltrækningskraft på mænd. Lægerne troede, at lesbiske var mænd, der blev holdt fanget i kvindekroppe, og som var maskuline i deres måde at være på og derfor også seksuelt interesseret $\mathrm{i}$ kvinder. ${ }^{43}$

Selvom ordene heteroseksuel og homoseksuel havde eksisteret som begreber for seksuel orientering siden midten af 1800tallet, var det lægerne, der i starten af 1900-tallet introducerede lesbiske som en decideret seksuel afvigelse. Lægernes stempling af homoseksualitet som en seksuel afvigelse er blevet kædet sammen med den indflydelse, som eugenikken havde i 1930'erne. Ud fra et ønske om at forbedre befolkningens sundhed blev mennesker kategoriseret i forskellige grupper. Homoseksualitet befandt sig på den nederste del af denne sociale rangstige. ${ }^{44}$

I 1959 blev første kapitel i dansk kvindefodbold ifølge ugebladsjournalisten Alf Mørkeberg taget:

»En 15-årig pige, Lene Jorgensen, beklagede sig over, at hun ikke kunne få lov at spille fodbold. Slagelse Firma Sports leder, Allan Andersen, fik ved et propagandastovne overtalt sygeplejerskerne ved Centralsygehuset og Andersvange $i$ Slagelse til at spille en kamp mod hinanden. Femina overvarede kampen og inviterede de to hold til Kobenhavn «. ${ }^{45}$

Kampen i København blev vist i fjernsynet og gjorde tanken om kvinder, der spiller fodbold, mere konkret. Alf Mørkeberg blev inspireret af Lene Jørgensens artikel i den lokale fodboldklubs medlemsblad og tog initiativ til en pokalturnering i fodbold for kvinder. Interessen for at deltage i pokalturneringen var stor. Således blev der i løbet af det første år med kvindefodbold i Danmark dannet 150 klubber, hvor der blev spillet kvindefodbold. ${ }^{46}$

Selvom Mørkeberg gjorde et stort arbejde for, at kvindefodbold skulle tages alvorlig, var holdningerne til kvindefodbold i den offentlige debat for det meste præget af latterliggørelse eller decideret uvilje. Mørkeberg citerer således træneren for ugebladet Feminas eget hold, Per Henriksen, for »at more sig fortraffeligt ved at se på kvindefodbold, fordi at der opstår ustyrligt morsomme situationer $«{ }^{47} \mathrm{Og}$ en $\mathrm{Ha}-$ derslev-avis udtrykker stor betænkelighed over kvindefodbold, og er sikker på, at mændene inden fem-seks år vil komme til at fortryde, at kvinderne fik lov til at komme ind på fodboldbanerne. ${ }^{48}$ Anderledes positiv er Ekstra Bladets Julius Larsen citeret for at være. Han omtaler kvindefodbold »som ikke noer så hård som kvindehåndbold« og beskriver kvindefodbolden som en feminin idræt, hvor »pigerne afslфrer god balance og er fri for alle de albuer, som de knalder ind $i$ brystet på hinanden $i$ håndbold «. ${ }^{49}$

Selvom Femina i forbindelse med et redaktørskifte ophører med at interessere sig for kvindefodbold, fortsætter Mørkeberg sammen med fire repræsentanter for fodboldklubberne Femina, Sundby, Roskilde og Rødovre med at arrangere fodboldkampe for kvinder op gennem 1960'erne. Organiseringen af disse kampe var uofficiel, uden protokoller eller mødereferater. »Vi mфdtes blot, når der var behov for det og snakkede sammen efter kampene «. ${ }^{50}$

På det organisatoriske plan omtalte Mørkeberg allerede i 1960 både et sjæl- 
landsk og et jysk kvindeligt fodboldforbund..$^{51}$ I marts 1971 bliver en sammenlægning af de to fodboldforbund en realitet og et foreløbigt landsforbund for kvindefodbold DKFU (Dansk Kvinde Fodbold Union), stiftet. Samme år søger forbundet om optagelse i DIF, men bliver afvist $i$ henhold til de internationale regler i FIFA (Fedération Internationale de Football Association), som kun tillader et nationalt fodboldforbund.$^{52} \mathrm{Et}$ år senere blev DKFU derfor opløst, og i stedet for blev kvindefodbold optaget i DBU's (Dansk Boldspil Union) lokalunioner.

Optagelsen i DBU var tilsyneladende ikke en opgave, som DBU ønskede at påtage sig. Således skulle der gå 10 år, før der i 1981 blev lavet en landsdækkende elitedivision for kvinderne. Det organisatoriske systems træghed og manglende opbakning til kvindefodbold bliver i 1987 af den daværende kvindefodboldlandsholdstræner karakteriseret på følgende måde:

$» K v i n d e f o d b o l d e n$ er idrattens 'stedbarn'. De gamle mand i DBU og FIFA tilsidesatter kvinderne og slфser med tilrettelaggelsen af de internationale turneringer $\ll{ }^{53}$

\section{Reprasentationer af homofobi $i$ den danske avispresse}

På trods af at kvindefodbolden får status af at være en officielt anerkendt sportsaktivitet for kvinder, kan det med udgangspunkt i homofobi-begrebet hævdes, at modstanden imod kvindefodbold i stedet manifesterer sig i homofobiske holdninger til de kvinder, der spiller fodbold. Alligevel er det først i 1980'erne, at der uafhængig af kvindernes seksuelle identitet i $\varnothing v$ vrigt ses en egentlig sammenkædning af fodbold- spillende »maskuline « kvinder og homoseksualitet. Der er således ikke langt fra antagelsen om kvinders manglende seksuelle attraktivitet for mænd til påstanden om, at de sportsaktive kvinder i stedet for må være seksuelt attraktive for andre kvinder. $^{54}$

I Norge og Sverige har kvindefodbold haft en langt større tilslutning af aktive spillere end i Danmark. Det norske kvindefodboldlandshold har været verdensmestre og er OL-mestre fra Sydney 2000 og har været blandt verdens bedste i de sidste 20 år. Det svenske kvindefodboldlandshold er europamestre fra 1984, fik sølvmedaljer ved EM 2001 og rangerer i henhold til den seneste officielle rangeringsliste fra UEFA (United European Football Association) som Europas tredje bedste kvindefodboldlandshold

Derfor har kvindefodbold i Norge og Sverige haft en højere grad af mediebevågenhed. Set i forhold til Danmark har de kvindelige fodboldspillere i Norge og Sverige derfor også været udsat for en større grad af medieeksponering. Denne omtale har været præget af homofobiske holdninger til kvindefodbold.

Når kvindefodbold bliver præsenteret $\mathrm{i}$ den skrevne presse i Danmark, falder interessen sig inden for forskellige hovedområder: Landsholdets deltagelse i forskellige internationale turneringer med VM i 1999 og EM i 2001 som de to kvindefodboldbegivenheder, der har haft størst mediebevågenhed i Danmark inden for de sidste fem år. Derudover er der portrætter af fremtrædende kvindelige landsholdsspillere og omtale af den nye kvindefodboldlandsholdstræner Poul Højmose. FB's (Frederiksberg Boldklub) satsning på kvindefodbold får en del opmærksomhed: Ansættelse af en professionel træner, fire amerikanske kontraktspillere i klubben og 
en kendt københavnsk ejendomsmægler som sponsor for FB er »gode « historier i aviserne. Derudover er det umiddelbare billede, man får af at læse om dansk kvindefodbold i aviserne, en sport der har svært ved at skabe gode resultater på det internationale plan.

Bortset fra OL i 2000 har det danske landshold i kvindefodbold kvalificeret sig til stort set alle betydningsfulde turneringer som OL i 1996, EM i 1997, VM i 1998 og EM i 2001, men resultaterne i disse turneringer er udeblevet. Semifinalepladsen ved EM i 2001 er det bedste internationale resultat, kvindelandsholdet har haft i mange år.

Men (re)præsenterer avisernes billeder i deres fremstilling også homofobiske holdninger til kvindefodbold? Jeg har valgt at inddele de udvalgte artikler i forskellige temaer.

\section{»Damefodbold« eller $» k v i n d e f o d b o l d «$}

Selvom ordet kvindefodbold ifølge Dansk Sprognævn er blevet en del af det officielle danske sprog i $1996,{ }^{55}$ er damefodbold stadigvæk DBU's officielle ord for kvindefodbold. Ifølge Nudansk ordbog er en dame, »en dannet, fin kvinde«, hvorimod $» k v i n d e$ er udtrykket for en »voksen person af hunkøn«. Sprogligt set er kvindefodbold derfor et mere korrekt ord at bruge, hvis ordet skal udtrykke kvinder, der spiller fodbold. Man kan hævde, at DBU ved at fastholde damefodbold som betegnelsen for kvinder, der spiller fodbold, udtrykker en homofobisk holdning til kvindefodbold, fordi begrebet er med til at forstærke det heteroseksuelle udtryk, som sporten signalerer. Med udtrykket damefodbold bliver det feminine udtryk således understreget, så der ikke skal være nogen tvivl om, at damefodbold repræsenterer kvindelighed og dermed også en heteroseksuel orientering. Alligevel er der grund til at være forsigtig med at tolke DBU's fastholdelse af damefodboldbegrebet som homofobisk, idet begrebet også kan forstås som en modsætning til herrefodbold. Der er eksempelvis ikke en pendant til ordet herrefodbold på samme måde - mandefodbold eksisterer således ikke ifølge Dansk Sprognævn.

Jeg har valgt at fremhæve damefodboldbegrebet i en homofobisk betydning - ikke mindst fordi jeg selv foretrækker kvindefodboldbegrebet, der signalerer, at det er kvinder, der spiller fodbold. Det er i denne forbindelse værd at bemærke, at en navneændring fra damefodbold til kvindefodbold blev foretaget i England allerede i 1969 i forbindelse med dannelsen af WFA (Women's Footbal Assosiation). »Ladies play golf - women do athletics and football«, som Olive Newsom fra det nystiftede fodboldforbund udtalte. ${ }^{56}$

\section{"Livet er for kort til kvindefodbold «}

Engang var livet for kort til at spille kvindehåndbold. Den sportslige succes, som det danske kvindelandshold $\mathrm{i}$ håndbold har haft, har gjort denne spydighed om kvindehåndbold til skamme, men klichéen bliver i stedet for anvendt i talrige avisartikler om kvindefodbold. Selvom selve klichéen refererer til det danske kvindefodboldlandsholds sportslige fiaskoer i de internationale turneringer, de har deltaget i, kan et liv uden kvindefodbold være et $\emptyset$ nske om at genvinde et maskulint terræn. Klichéen er altså også et udtryk for, at fodbold skal være en sport udelukkende for mænd, hvor mandige dyder som styrke, udholdenhed 
og aggression kan trænes.

Træneren for herrernes U16-landshold Hans Brun Larsen udtaler med »livet er for kort til kvindefodbold « som overskrift, at kvindefodbold er forkert, tungt og klodset. Der eksisterer en direkte ubalance mellem kvinder og fodbold, som Hans Brun Larsen tilskriver kvinders fysik og mentalitet. Derudover mangler kvinder evnen til at arbejde sammen på en fodboldbane. Kvinderne prioriterer i stedet for at hygge sig og så kan man ikke kalde det fodbold. ${ }^{57}$ Hans Brun Larsens kommentarer om kvindefodbold som et socialt arrangement, snarere end en konkurrencesport, virkede voldsomt provokerende på det kvindefodboldseminar, han deltog i. Men samtidig kan hans kommentarer også tolkes som en accept af kvindefodbold, uden at kvindefodbold i Hans Brun Larsens forståelse derved bliver respekteret på lige fod med herrefodbold.

Samme aspekt er DBU's informationschef, Lars Berendt, inde på. »Vi bruger millioner på damefodbold «, siger han som svar på pressens kritik af DBU's manglende interesse i kvindefodbold. Samtidig understreger han, at kvindefodbold aldrig bliver nogen god forretning for DBU. Han fremhæver, hvorledes DBU igennem deres $»$ Struktureret Talent Udvikling « og »Pigeraketten « har lavet en kvalitativ satsning inden for kvindefodbold, som gerne skulle være med til at få medlemstallet i DBU til at runde de 300.000. »Målet kan kun nås med flere pige- og damespillere «, som Lars Berendt udtrykker det. ${ }^{58}$ Selvom kvindefodbold ligger ude i periferien af, hvad der er »rigtig « fodbold, kan kvindefodbold bruges til at sætte nye rekorder for DBU.

I forbindelse med Team Danmarks udvikling af et ambitiøst eliteprojekt, der skal være med til at sikre dansk kvindefodbold en position blandt de tre bedste nationer $\mathrm{i}$ verden, har DBU's bestyrelse valgt kun at støtte dele af projektet. DBU's formand, Poul Hyldgaard, er skeptisk over for projektet.

$\gg$ Det er et noget ambitiøst projekt. Spфrgsmålet er ikke, hvorvidt vi har pengene. Det er mere en vurdering af det fornuftige $i$ at bruge dem på så få spillere uden DBU egentlig fär noget igen. Vi bruger også mange penge på mandenes A-landshold, men de penge fär vi tilbage mange gange $\ll .59$

Team Danmarks sportschef, Susanne Hedegaard, er skuffet over, at DBU kun støtter projektet delvist.

»Skal der satses helhjertet, kraver det opbakning og ikke en holdning om, at livet er for kort til kvindefodbold. Den bemarkning hører jeg tit. Vi kan ikke garantere, at projektet bliver en succes, men det forventer vi. Men uden opbakning i dansk fodbold kan det aldrig blive det $«{ }^{60}$

Anderledes mere direkte i sin kritik af DBU's holdning til kvindefodbolden er Thomas Grøndorf:

»... Det virker lidt komisk, at DBU taler om ligevard, når man ser på, hvordan $D B U$ har handlet og toenker i forhold til kvindelandsholdet. Lars Berendt sidestiller kvindelandsholdet med andre bredderelaterede tiltag, som DBU støtter $\phi$ konomisk ${ }^{61}$

\section{»Ingen plads til starke dameben «}

Der er blevet peget på benenes brug i fodbold som årsag til, at kvindefodbold har 
haft svært ved at blive accepteret som en sport for kvinder. Kvindefodbold kræver muskuløse og kraftige ben, hvilket kan være i konflikt med, hvad den fremherskende tilladte norm for kvindelighed kræver.

Bonde påpeger således følgende $\mathrm{i}$ et interview om kvindefodbold:

»Hold kaft, hvor er det grimt og ukvindeligt. Kvinder med starke ben. Det synes vi ikke er sexet. Sådan tonker mand, når snakken falder på kvindelige fodboldspillere ${ }^{62}$

Det er i denne forbindelse vanskeligt at bedømme, om Bonde udtaler sig som forsker, eller om han udtaler sig som privatperson. Under alle omstændigheder er der flere eksempler $\mathrm{i}$ aviserne på, at fodboldspillende kvinder ikke kan kategoriseres som kvindelige.

Politiken har eksempelvis spurgt en række anonyme kvinder og mænd, hvornår man er henholdsvis umandig og ukvindelig. En 44-årig mand er ikke i tvivl om, at kvindefodbold er ukvindeligt, selvom han ikke kan svare på, hvorfor det er det. Han finder det mærkværdigt, for kvindehåndbold »går det jo godt nok med «. ${ }^{63}$

I et læserbrev fra en kvinde udtrykkes det ukvindelige ved kvindefodbold mere klart:

»... For der findes ikke noget mere ucharmerende end kvindefodbold, og det er ganske vist også begranset, hvor meget appeal de noget tykke lårmuskler har $\ll .{ }^{64}$

Den tidligere danske landsholdstræner Richard Møller Nielsen udtaler sig på følgende måde om kvinder og kvindefodbold: »De skal passe på benene, for når de en- gang skal føde, skal de også føde kommende generationer fodboldspillere «. ${ }^{65}$

I et interview med den daværende kvindelige landsholdsspiller i fodbold, Bonny Madsen, bliver hun i overskriften kaldt Bonny Bomstærk. På denne måde fremhæves den kvindelige fodboldspillers maskuline væremåde. Der tegnes igennem hele interviewet et maskulint billede af Bonny Madsen. Hun bliver beskrevet som en »stor kleppert«, der har »kropsstyrke« og masser af energi. Hendes entydige drengerolle fremhæves på forskellige måder: »Jeg gik altid i sportssko og havde kort mikrofonhår«. Hendes forhold til en veninde beskrives som drengeagtigt, og hun citeres for at hilse på en veninde ved at dunke hende i ryggen. Derudover bliver hun spurgt, om hun stadigvæk er maskulin. Til sidst i interviewet bliver Bonny Madsens heteroseksuelle orientering fremhævet flere gange. Hun er blevet forladt af sin daværende kæreste og er flyttet til København. Dette har betydet en ændring i Bonnys liv på flere måder. Fodbolden tages ikke så seriøst mere:

»Jeg kunne aldrig gå med i byen i weekenden, fordi jeg skulle trane. Alkohol var bandlyst, og jeg bestilte ikke meget andet end at trane, sove, spille«.

$\mathrm{Nu}$ er der blevet plads til at gå i byen og kigge efter drenge. Og hun har skiftet hele sin garderobe ud - »Nu har jeg fäet nogle rigtig frokke Hapser-kjoler, højholede sko og gamacher $\ll .{ }^{66}$

Fremhævelsen af skiftet i Bonny Madsens liv fra at have været elitefodboldspiller og til at være motionistfodboldspiller forstærker indtrykket af den maskuline kvindelige fodboldspiller, som er blevet betonet igennem hele interviewet. Det er først, da Bonny Madsen ikke længere tager 
sin sport seriøst, at hun begynder at fremtræde mere feminint.

\section{»Så lange de ikke gфr en sag ud af det ... « ${ }^{67}$}

Homoseksuelle kan godt få lov til at dyrke fodbold, så længe de ikke gør en sag ud af det. Alligevel huserer der blandt homoseksuelle mænd en joke, der lyder således: »Blev du også valgt fra til fodbold? ${ }^{68}$

Der er ikke meget, der tyder på, at de danske aviser angriber danske sportsudøvere direkte for at være lesbiske - i hvert fald ikke i kvindefodbold, og homoseksualitet og kvindefodbold er ikke et emne, der bliver anvendt megen spalteplads på.

En artikel omhandler homoseksuelles vilkår i sport generelt. Den hollandske antropolog Gert Hekma påpeger, at kvindefodbolden er en af de eneste sportsaktiviteter, hvor homoseksuelle har haft mulighed for at bryde den tavshed, der ellers præger homoseksuelle i sport. ${ }^{69}$

Derudover er der et interview med den daværende brasilianske landsholdstræner i herrefodbold om kvinder og fodbold. Han påpeger, at der i Brasilien stadigvæk er en udbredt opfattelse af, at kvinder er lesbiske, når de spiller fodbold..$^{70}$

Anderledes aggressivt udtaler den tidligere Ikast-træner, Lennart Söderberg, sig i Ekstra Bladet om emnet: »... inden for kvindefodbold, der må du ikke vare med, hvis du ikke er lebbe «. ${ }^{71}$ Søderberg udtrykker med sine udtalelser ikke kun en homofobisk holdning til kvindefodbold, men er også med sine udtalelser direkte homonegativ i forhold til at have homoseksuelle i sin klub. Bøsser vil ifølge Søderberg således få »sparket« ud af fodboldklubben.

\section{»Skinken scorer ${ }^{72}$}

Skinken hentyder til den amerikanske kvindelige landsholdsspiller Mia Hamm. Hun betegnes som USA's bedste fodboldspiller. Derudover medvirker Mia Hamm som privatperson i forskellige marketingskampagner. I forbindelse med verdensmesterskabet i kvindefodbold i USA i 1999 deltog hun eksempelvis i et salgsfremstød for en fodboldsparkende barbiedukke: »Barbie og VM $i$ kvindefodbold har det falles mål at inspirere den kommende generation af unge kvinder til at drage fordel af de voksende muligheder, de får, både på fodboldbanen og uden for «, citeres Mia Hamm for at have sagt. ${ }^{73}$

Barbiedukken er med sine lange tynde ben og langt lyst hår, høje stilethæle og makeup selve symbolet for, hvad der, $\mathrm{i}$ forhold til normerne om kvindelighed, må opfattes som kvindeligt. Under VM i USA repræsenterede den fodboldsparkende barbiedukke kvindefodbold. Herved fors $\emptyset$ gte man at fremhæve de kvindelige sider af kvindefodbold.

Ekstra Bladets journalist Povl HøstMadsen er under VM blevet sat til at skrive om de amerikanske fodboldsupportere, »men til amerikansk kvindefodbold kommer der hovedsageligt pane små piger sammen med deres forceldre [...] 70.000 hysterisk skrigende amerikanske børnefamilier på et fodboldstadion, er virkelig ikke noget at skrive hjem om ... Det mindede mere om en familieskovtur $«{ }^{74}$ replicerer han om en af de fodboldkampe, han overværer.

Informations Øjvind Hesselager skriver i sin artikel om åbningskampen under verdensmesterskabet i USA, at de danske fodboldkvinder havde de »poneste frisurer $« .{ }^{75}$

En journalist fra Ekstra Bladet har fået lov til at følge en af FB's kampe, både på 
og uden for banen. »Hvis det ikke lige var for den sloggi-bh, der ligger henkastet på massagebonken, kunne det lige så godt vare i FCK's omklaedningsrum «, bemærker han. Om den kvindelige fodbolddommer fremhæver han følgende: »Danmarks smukkeste dommer «, ikke et ord om hendes præstation som dommer. ${ }^{76}$

Den dansk-amerikanske kvindelige fodboldspiller Mikka Hansen er kommet til Danmark for at spille professionel fodbold i FB. I den forbindelse har klubbens direktør, Alex Høgh, planlagt at medieeksponere Mikka Hansen på forskellige måder. Fodboldspilleren er eksempelvis af ugebladet Se og H $\phi r$, blevet bedt om at stille op til en nøgenfotografering, kun iført slips. »Det er en bevidst pr-strategi fra vores side«, udtaler Alex Høgh og fortsætter:

»Havde Mikka ikke varet køn og sporty, men lille og buttet, havde vi varet nodt til at andre strategi [...] Vi bruger spillernes kvindelighed - det er da interessant at se dem have mudder på knceene den ene dag og gå modeshow den anden dag $\ll{ }^{.7}$

I et interview med den kvindelige professionelle fodboldspiller i Fullham i England, Katrine Petersen, er denne måde at medieeksponere kvindelige fodboldspillere også fremtrædende:

»... der bliver satset en del på at markedsføre fodbolden. Klubben gør meget $u d$ af, at vi siger de rigtige ting og $g \phi r$ noget ud af, at vi er kvinder. Der har varet tv-hold herude, og vi har varet til sådan nogle make-overs, hvor vi forst blev fotograferet i fodboldt $\phi j$, og så bagefter $i$ kjoler med fuld makeup. Jeg ved ikke rigtig, om jeg kan lide det, men det er nok vigtigt at vise, at vi ikke bare er kvinder, der prøver at ligne mandlige fodboldspillere ${ }^{78}$

»Hvordan salger man et vaskepulver, der kun virker hver anden gang? «"79

Spørgsmålet blev stillet på et seminar om kvindefodbold i 1998 og er ifølge artiklen symptomatisk for de problemer, som dansk kvindefodbold har. Kvindefodbold er ikke interessant og leverer tilsyneladende kun den rigtige »vare« en gang imellem. Og hvis »varen « bliver leveret, er det ikke engang sikkert, at aviserne har journalister på stedet til at reportere om »vaskepulverets «' kvaliteter, således som det tilsyneladende er tilfældet, når kvindelandsholdet $\mathrm{i}$ fodbold spiller en kamp i Danmark. ${ }^{80}$

Dansk kvindefodbold står i periferien af dansk herrefodbold, og det afspejles tydeligt set i forhold til det billede, der tegnes af kvindefodbold i de danske aviser. DBU har i løbet af 1990'erne sat en lang række projekter i gang, der viser, at fodboldforbundet satser på en fremtid for dansk kvindefodbold. I 1994 bliver »Struktureret talent Udvikling « iværksat i samarbejde med Team Danmark. På lokalplan er »Pigeraketten « det seneste fors øg på at få flere piger til at spille fodbold. Pige- og kvindefodbold er blevet accepteret og kan endda bruges af DBU i et fremstød til at $\varnothing$ ge medlemstallet i specialforbundet, men respekten for kvindefodbold som en konkurrence- og eliteaktivitet er svær at få øje på. DBU's skepsis og ulyst til at deltage fuldt ud i Team Danmarks millionsatsning på kvindefodbold i Danmark er det seneste eksempel på DBU's manglende respekt for kvindefodbold.

Når kvindefodbold medieeksponeres, er det gennemgående indtryk derfor stadig- 
væk på mange måder en latterliggørelse af sporten. Jævnfør eksempelvis Ekstra Bladets Poul Høst Madsens kommentarer til verdensmesterskabet i kvindefodbold i 1999. Fremhævelsen af den maskuline fodboldspillende kvinde med de underliggende homofobiske holdninger til kvindefodbold er et andet eksempel på denne »gøren grin« med sporten. Denne »gøren grin« med sporten vil formentlig være svær at slippe af med, før kvindefodbold i Danmark har skabt sig positive resultater i en af de internationale turneringer, kvindefodboldlandsholdet kvalificerer sig til.

Med Danmarks semifinaleplads under EM i 2001 er vejen til en større respekt for kvindefodbold muligvis skabt. Både spillere og træner på det danske EM-hold giver efter EM 2001 udtryk for dette. Den kvindelige danske landsholdspiller Merete Pedersen udtrykker det således:

»... og forhåbentlig betyder det, at pigeog kvindefodbolden i Danmark generelt får mere respekt. Vi traner og arbejder knaldhårdt. Vi er bare aldrig blevet respekteret for det «. ${ }^{81}$

Alligevel er der tegn på ændringer i det billede, som aviserne fremstiller af kvindefodbold. Det er specielt de to portrætter af Mikka Hansen fra 1999 og Katrine Petersen fra 2001, som adskiller sig fra det $\varnothing v$ vige materiale. Hvor man tidligere har haft en tendens til at fremstille et maskulint billede af fodboldspillende kvinder, er det $\mathrm{i}$ disse portrætter modsætningerne i det kvindelige, henholdsvis det mandlige, der er i fokus. Som Katrine Petersen udtrykker det, »er det nok vigtigt at vise, at kvindelige fodboldspillere ikke bare er kvinder, der prover at ligne mandlige fodboldspillere«.

På denne måde bliver fokus lagt på kvindefodbolds forskellighed fra herrefodbold. Spørgsmålet er, om ikke dette er vejen frem, hvis kvindefodbold ikke kun skal vinde accept, men også respekt som en sportsaktivitet for kvinder.

\section{Noter}

1. D. Whitson, »Sport in the Social Construction of Masculinity« I: M.A. Messner, \& D.F. Sabo, Sport, Men and the Gender Order - Critical Feminist Perspectives (Campaign, 1990).

2. J. Hargreaves, Sporting Females-Critical Issues in the History and Sociology of Women's (London, 1994).

3. K. Fasting, »Homofobi i toppidretten« I: S. Loland (red.), Toppidrettens pris (Oslo, 1998a).

4. K. Fasting (1998a).

5. Episoden er beskrevet i L. Friis Thing, Sport - en emotionel affare - kvinder, holdsport og aggression Københavns Universitet, 1999).

6. Fjernsynsudsendelsen er beskrevet af Friis Thing (1999). Det er den danske idrætspsykolog Jens Hansen, der udtaler sig om kvindefodbold og homoseksualitet.

7. Den norske sociolog og idrætsforsker Kari Fasting er blevet opmærksom på denne problematik, fordi hun har deltaget i et større europæisk

forskningsprojekt vedrørende sportens rolle og betydning for kvinders liv, herunder kvindernes opfattelse af kvindelighed og mandighed. I den forbindelse blev rygterne om de mange lesbiske i kvindefodbold fremført af alle de kvinder, der blev interviewet. Fasting gennemførte derfor en særskilt undersøgelse, hvor de allerede gennemførte norske interview blev suppleret af interview med kvindelige elitefodboldspillere fra et tilsvarende antal svenske klubber, i alt 19 interview. Unders $\varnothing$ gelsen er beskrevet i følgende artikler: K. Fasting, »Homofobi og idrett. Kvinnelige fotballspilleres erfaringer «, paper presentert på konferensen »Frø og Frukter«, Nordisk kvinne- og kjønnsforskning d. 21.-23. November 1996; Fasting (1998a); K. Fasting, »Homofobi, kvinnor och eliteidrott - norske og svenske fotballspilleres erfaringer « I: Kunnskab om idrott, nr. 3 (2000). 
8. K. Fasting, »Farlige kvinder« I: Dansk Ungdom \& Idrcet, nr. 3 (1997).

9. C. Graugaard, Sexleksikon - fra abe til Aarestrup (Rosinante, 2001).

10. P. Griffin, Strong Women, Deep Closets - Lesbians and Homophobia in Sport (Champaign, 1998); J. Tangen, »Homofobi I kvinneidretten et litteraturstudie« I: Kunnskab om idrott, nr. 3 (2000); V. Krane, »Lesbians in Sport - Toward Acknowledgement, Understanding and Theory « I: Journal of Sport \& Exercise Psychology, nr. 18 (1996).

11. Krane, V.: »Lesbians in Sport - Toward Acknowledge, Understanding and Theory «.

12. P. Griffin, (1998); Fasting (1998a); Fasting (2000).

13. Graugard (2001).

14. Tangen (2000).

15. Kønsrollemønstre definerer Graugaard (2001) som de sider af et menneskes fremtoning og adfærd, som markerer det at være mand eller kvinde. Kønsroller defineres socialt, og givne kønsrollemønstre varierer betydeligt fra samfund til samfund.

16. L.-J. Kolnes, Kvinner og toppidrott. Om kjønn, kropp, seksualitet og relasjoner $i$ toppidretton (Oslo, 1994).

17. Fasting (1998a).

18. Gruagaard (2001).

19. Tangen (2000).

20. Fasting (1998a).

21. Kolnes (1994).

22. Fasting (2000).

23. Griffin (1998).

24. Hargreaves (1994); Kolnes (1994) og (2000); B. Cox, og S. Thompson, »Multible Bodies Sportswomen, Soccer and Sexuality « I: International Review for the Sociology of Sport, nr. 35-1 (2000).

25. Cox og Thompson (2000).

26. Griffin (1998).

27. Tangen (2000).

28. Griffin (1998).

29. Fasting (1998a).

30. Griffin (1998).

31. Fasting (1998a).

32. Cox og Thompson (2000).

33. Den gryende kvindebevægelse gjorde, at mændene følte sig truet på deres mandighed, og fik en del mænd til at »smede en identitet omkring en fast og afgranset karakter og et hardet legeme«.

34. Tangen (2000).
35. L. Ottesen, »En etnologisk synsvinkel på kvindefodbold 2« I: Focus Damefodbold, nr. 5 (1985a).

36. B. Rosenbeck, Kroppens politik - Om køn, kultur og videnskab (København, 1992).

37. Ibid.

38. E. Trangbæk (red.), Dansk Idræetsliv - den moderne idrats gennembrud 1860-1940, bind 1 (Gyldendal, 1995).

39. Ifølge Graugaard (2001) er amazoner et oldgræsk krigerfolk fra Lilleasien. Bestod udelukkende af vilde, barbariske kvinder, som udmærkede sig ved krigerisk mod; for bedre at kunne spænde buen brændte de det højre bryst bort. Kæmpede som Trojas forbundsfæller mod grækerne. Legenden om de utæmmelige kvinder kan ses som en allegori over mænds angst for kvindelig seksualitet.

40. H. Bonde, Mandighed og sport (Odense, 1991).

41. Fasting (1998a) refererer til den amerikanske forsker S.K. Cahns analyse af den amerikanske kvindeidrætshistorie: Coming on Strong. Gender and Sexuality in Twentieth Century Woman's Sport (New York, 1994). Griffin (1998).

42. Griffin (1998).

43. Fasting (1998a).

44. Griffin (1998).

45. Femina, nr. 11960.

46. Femina, nr. 311960.

47. Femina, nr. 251960.

48. Femina, nr. 211960.

49. Femina, nr. 311960.

50. L. Ottesen, »En etnologisk synsvinkel på kvindefodbold 3«I: Fokus Damefodbold, nr. 6 (1985b).

51. Ibid.

52. L. Ottesen, »Hvornår begyndte kvinder at spille fodbold?« I: E. Trangbæk (red.): Den engelske sports gennembrud i Norden, Dansk Idrætshistorisk Forening, Krop og Kultur (1989).

53. Ibid.

54. Fasting (1998).

55. »Rød ordbog angriber den grønne« I: Jylland-Posten, (11/9 1996.

56. S. Lopez, Women on the Ball - a guide to Women's Football (London, 1997).

57. »Damefodboldens status til debat« I: Dansk Fodbold, nr. 2 (1998).

58. »Vi bruger millioner på damefodbold « I: Kridtstregen, maj 1999.

59. »Kvindefodbold: Skepsis mod million-satsning « I: Jyllands-Posten, 17/5 2001.

60. »Kvindefodbold: DBU under stærkt pres« I: $J y l$ lands-Posten, 20/5 2001. 
61. »Debat: Usynlig organisation« I: Politiken, 6/8.

62. »Ingen plads til stærke dameben « I: Politiken, 22/6 1998.

63. »Tarzan og Jane: Rigtige kvinder bøvser ikke Rigtige mænd strikker ikke« I: Politiken, 27/11 2000.

64. »Jeg elsker fodbold, drenge« I: Politiken, 10/6 1998.

65. »Ricardo på glatis« I: Ekstra Bladet, 16/5 2000.

66. »Bonny Madsen: Bonny Bomstærk« I: Ekstra Bladet, 24/9 1994.

67. »Så længe de ikke gør en sag ud af det« I: Politiken, $21 / 22000$.

68. Ibid.

69. Ibid.

70. »Mit liv drejer sig om fodbold« I: Politiken, 31/3 1996.
71. »Bøsser får et los« I: Ekstra Bladet, 30/6 1999.

72. »Fodbold: Klart dansk nederlag« I: Information, 21/6 1999.

73. »Madsen: Barbie - USA's hemmelige våben« I: Ekstra Bladet, 19/6 1999.

74. »Madsen: Nedtur« I: Ekstra Bladet.

75. »Fodbold: Klart dansk nederlag« I: Information, 21/6 1999 .

76. »Byens hun-hold« I: Ekstra Bladet, 2/10 1999.

77. »Fodbold: Mikka har bolden« I: Ekstra Bladet, $15 / 51999$.

78. »Profession: Fodboldspiller« I: Politiken, 6/8 2001.

79. Se note 57.

80. Se note 58.

81. »Kvindefodbold: Fagre nye verden« I: Ekstra Bladet. 3/7 2001. 